\title{
Geological and Geotechnical State of the Nisane Khola Landslide, Dharan, Sunsari, Nepal - A Case Study
}

\author{
${ }^{a}$ Drona Adhikari*, ${ }^{a}$ Champak Babu Silwal, ${ }^{a}$ Suraj Giri
}

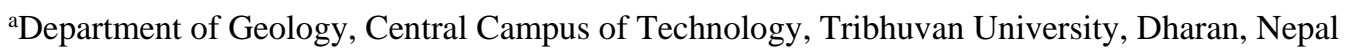

*Corresponding email: drona.adhikari@cct.tu.edu.np

\begin{abstract}
Geological and landslide mapping was carried out in order to delineate the geological and geotechnical state of the Nisane landslide, situated in Dharan Sub-Metropolitan City, Sunsari, Nepal, which has been obstructing the Koshi Highway time and again. The affected area bears metasedimentary and sedimentary rock sequences of the Lesser Himalaya and the Siwalik, respectively. The Dharapani Thrust separates the Chiuribas Formation and the Tamrang Formation of the Lesser Himalaya whereas the Main Boundary Thrust separates the Tamrang Formation and the Siwalik. The Nisane landslide is an old landslide situated in the structurally weak zone having variable activation period. Recently, the landslide reactivated as intense slide after the Gorkha Earthquake, 2015 and is occasionally obstructing the Koshi Highway. The subsidence in highway indicates the landmass is creeping along the tension crack. Kinematic analysis, Rock Mass Rating (RMR) and Slope Mass Rating (SMR), based on the field observation, measurement and laboratory testing, was carried out in eight different slopes of the slide. The results suggested majority of slopes suffers the wedge and plain failures along the major joint sets. The rock masses are of fair class and the slopes are unstable to partially stable. The slopes of major slide are vulnerable and seeks for immediate sustainable treatment.
\end{abstract}

\section{Introduction}

The Nisane Landslide lies within the Dharan sub metropolitan city, about $7 \mathrm{Km}$ towards Bhedetar along the Koshi Highway from the Zero Point of Dharan (Fig. 1). The crown part of the landslide $(760 \mathrm{~m})$ is accessible through the Koshi Highway, which connects the hilly regions of east Nepal with Terai, and the toe part through the Fusre-B.P. Park road of Dharan.

The area represents mixed geographic territory of Bhabar, Chure, and the Mahabharat Highlands. It has rugged topography and steep terrains, mostly covered by forest and some part by alluvial deposits of the Nisane Khola and tributaries of the Sardu Khola. Dharan is also known for second highest annual rainfall with average precipitation of $1799 \mathrm{~mm}$ per year. This attribute along with the structural complexity make the area prone to landslide especially during monsoon.

Geologically, it is the boundary region of three tectonic sequences; metasedimentary sequence of the Lesser Himalaya, sedimentary sequence of the Lesser
Himalaya (Gondwana Sequence) and sedimentary sequence of the Siwalik. DMG (2009) classified the rock sequence into the Lower Unit of the Midland Group, the Charchare Formation of the Gondwana Subgroup, the Lower Siwalik Formation, the Lower Middle Siwalik Formation and the Upper Middle Siwalik Formation. The area prevails consecutive presence of the thrust sheets, the Central Churia Thrust, the Main Boundary Thrust and the Mahabharat Thrust, in close succession and hence marked as the hazard prone area (DMG 2009). The map of DMG (2011) has revised the name of the Gondwana rock sequence as the Takure Formation and the Lower Unit of the Midland Group has been named as the Sangram Formation of the Lakharpata Subgroup. Dhital (2015) prepared the map consisting the study area and classified the area into Middle Siwalik and the Chiuribas Formation separated by the Dharapani Thrust. Rai et al. (2016) has marked the presence of Gondwana rock in the area and classified it as the Bhorleni Formation. Two consecutive thrust the 
Chhotimorang Thrust and the Main Boundary Thrust are present in close succession separating the rock sequences of the Chiuribas Formation from the Bhorleni Formation and the later with the Siwaliks, respectively (Rai et al. 2016). All the previous study indicated that the landslide bearing area is structurally weak zone and bears multiple thrust zones in close succession of horizontal distance suggesting that the area has suffered through multiple stages of deformation. Present study is focused on delineation of geological state of focused area in which the classification names adopted as presented by Dhital (2015) and Adhikari et al. (2018), and to find out geotechnical cause of the Nishane landslide that has been obstructing the traffic of the Koshi Highway.

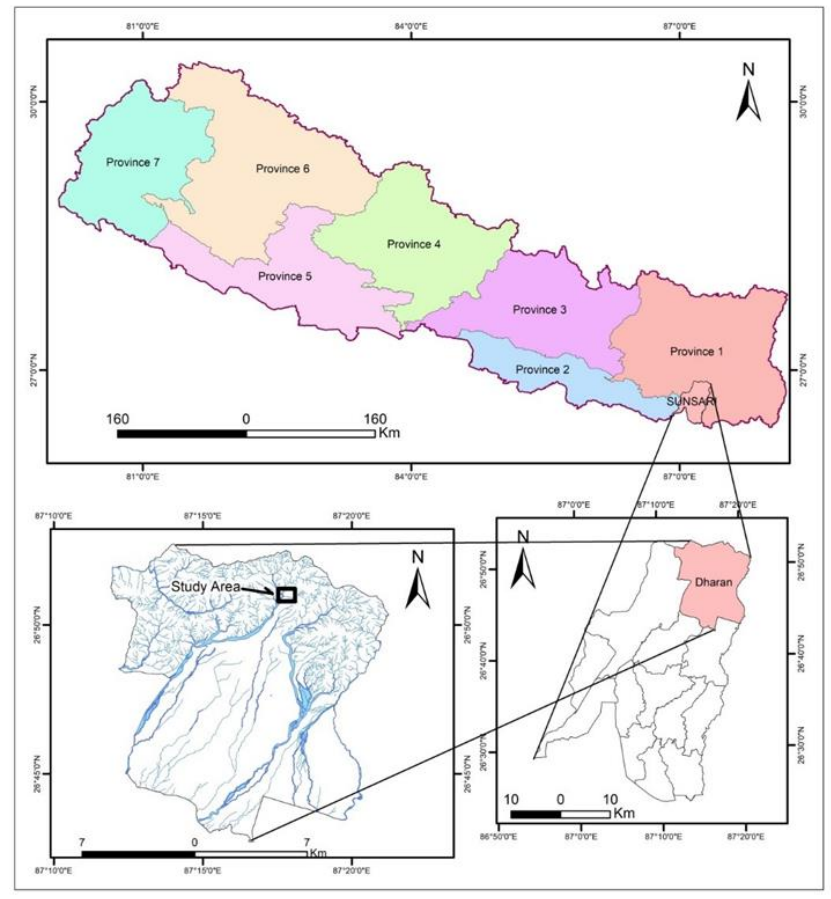

Fig. 1: Location map of study area

\section{Materials and Methods}

Intense review of geological work was carried out followed by field observations and measurements using standard geological instruments. The field study was carried out during September and October of 2019. In laboratory, the point load strength index of the rock sample (irregular rock block) was computed using the Indian Standard (IS 8764). The calculation and classification of point load strength was carried out as described by Hoek \& Brown (1997). The kinematic analysis was based on the Markland's test described in Hoek \& Bray (1981). The RMR basic was calculated using the method described by Bieniawski (1989). The SMR technique (Romana 1985) was used for the analysis of slope stability. Different graphical as well as data analysis tools/programs such as ArcGIS 10 (student version), Dips5.1, MS Excel, SMRToolbeta 1.07 (Requelme et al., 2014) etc. were used to digitize the map and analyze the collected data.

\section{Results and Discussion}

\subsection{Site geology}

The research area comprises of lithological sequences of the Lesser Himalaya and the Siwalik (Fig. 2).

\section{Lesser Himalaya}

\section{Chiuribas Formation}

The lithology comprises of greenish to dark grey 10$45 \mathrm{~cm}$ thick beds of quartzite and metasandstone alternating with green to grey phyllite. Occasional metabasic intrusions can also be observed. The metasedimentary sequence is separated from the rocks of the Gondwana sequence by the Dharapani Thrust (Fig. 3).

\section{Gondwana Sequence (Tamrang Formation)}

The Gondwana rocks can be observed upstream along the Nisane Khola from the Nisane Bridge on the Koshi Highway. This sequence consists of grey to black shale alternating with greenish to bluish grey, thick sandstone beds. This unit resembles with the Tamrang Formation of Barahakshetra section (Dhital 2015) which is separated from the Siwalik by Main Boundary Thrust (Fig. 4).

\section{Siwaliks}

The study area comprises of the rocks of the lower and the upper member of Lower Siwalik Formation. The classification is based on the basis of proportion of mudstone and sandstone Adhikari et al. (2018). The lower member comprises of purple, greenish grey to grey mudstone and shale alternating with 5 to $30 \mathrm{~cm}$ thick, fine to medium grained, bluish grey, calcareous to non-calcareous, sandstone, which transitionally passes to the upper member of the formation. The rocks of the upper member comprise of medium to coarse grained, thick bedded, bluish, grey to pinkish, calcareous to non-calcareous sandstone alternating with purple to grey mudstone that is truncated in the upper part by the Main Boundary thrust. 


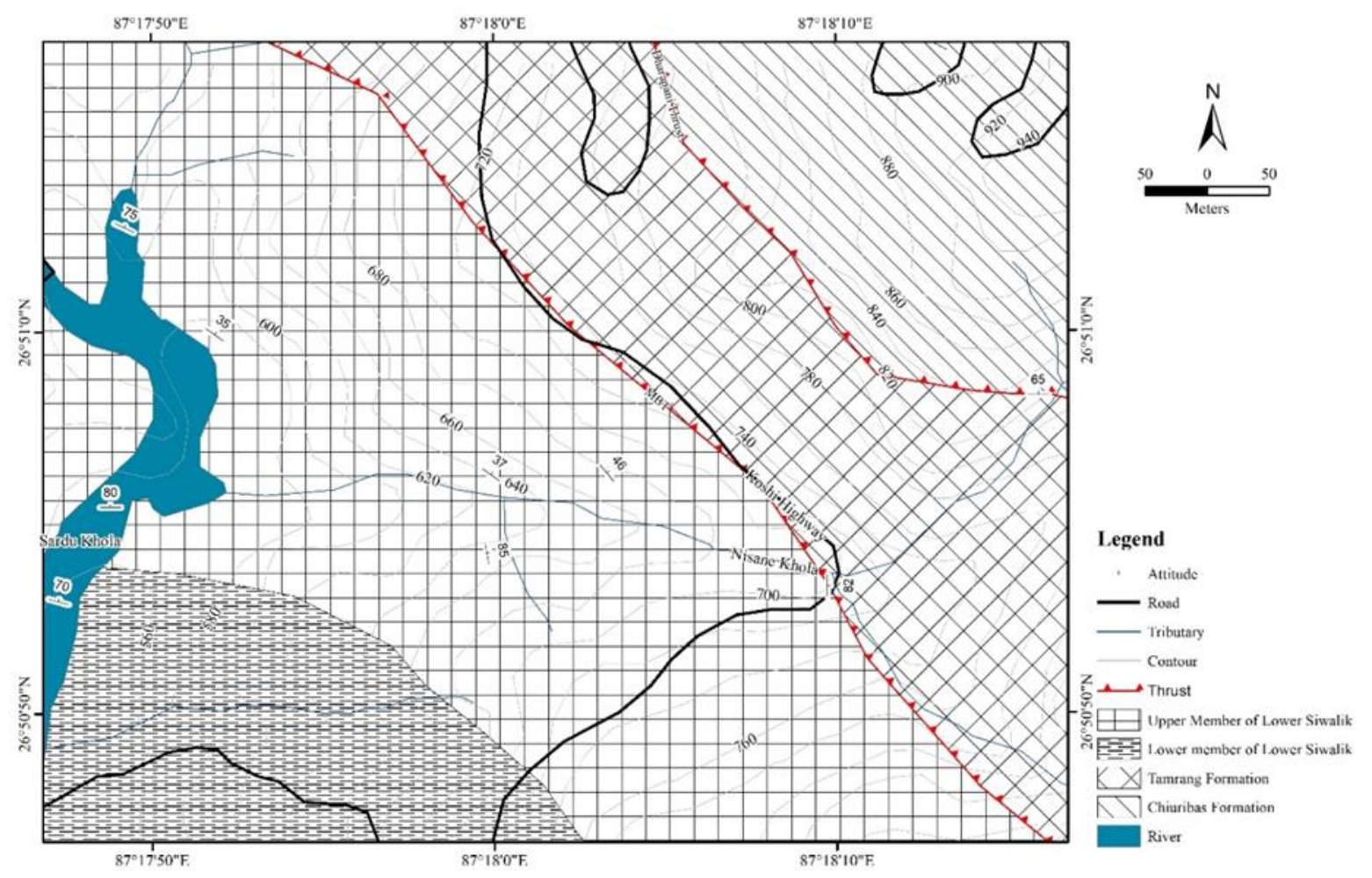

Fig. 2: Geological map of the study area

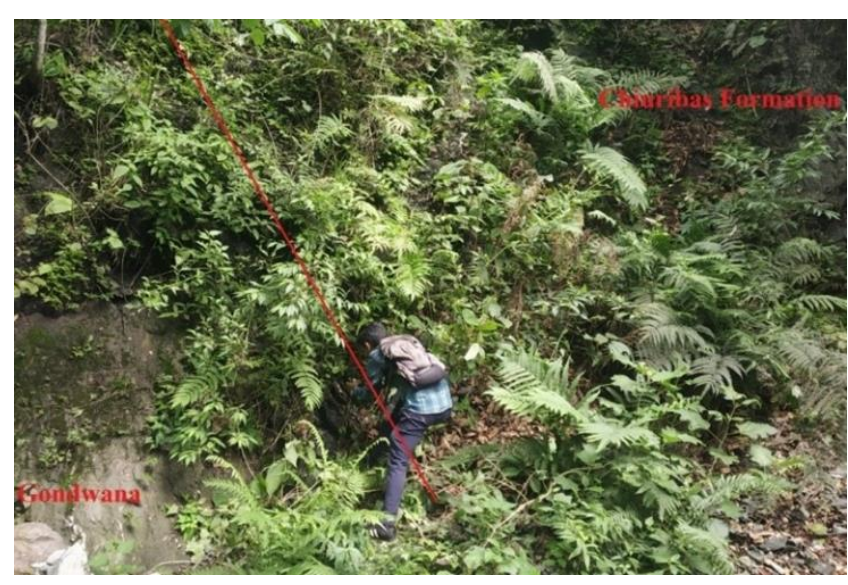

Fig. 3: Exposure photo showing boundary zone between rocks of the Chiribas Formation and Gondwana rocks about $200 \mathrm{~m}$ upstream along the Nisane Khola from the Nisane Bridge over the Koshi Highway

\subsection{Landslide Study}

An attempt was made to prepare the landslide map and cross-section (Fig. 5 and 6) in order to delineate the area affected by landslide. Altogether, three major scarps of landslides can be observed on the area (Fig. 5). The major emphasis has been given to the slide, which has obstructed the Koshi Highway. Some tension cracks (Fig. 7) and sign of creeping (bent trees stem) indicates ongoing deep-seated movement on the landmass added by the subsidence of some section of highway. Presently, gabion-benching structure has been installed to stabilize the slope at the crown of the slide, which seems to be insufficient in near future.

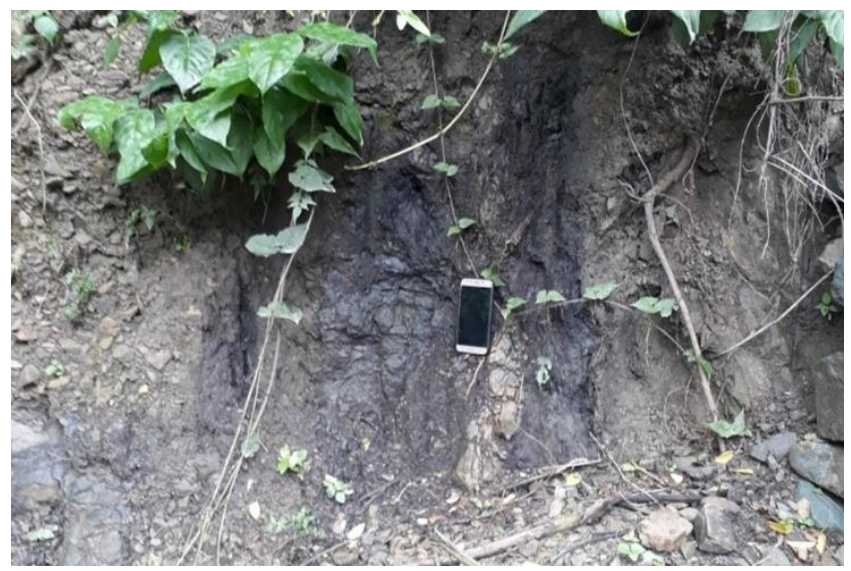

Fig. 4: Exposure Photo showing the boundary between the rocks of the Siwalik and Gondwana Seqences at the left bank of Nisane Khola at the Nisane Bridge on Koshi Highway

From the landslide map, surficial examination of ground movement and examination of landslide materials, some results have been drawn. All three scarps are the parts of single creeping mass bounded by tension cracks at the top. High precipitation rate of Dharan and high gradient of the Nisane Khola seems to be main reason that prohibited the accumulation of landslide material at its toe part. This toe scouring has lead major scarp to extend its area and it seems to continue further. On the other hand, the low gradient of 


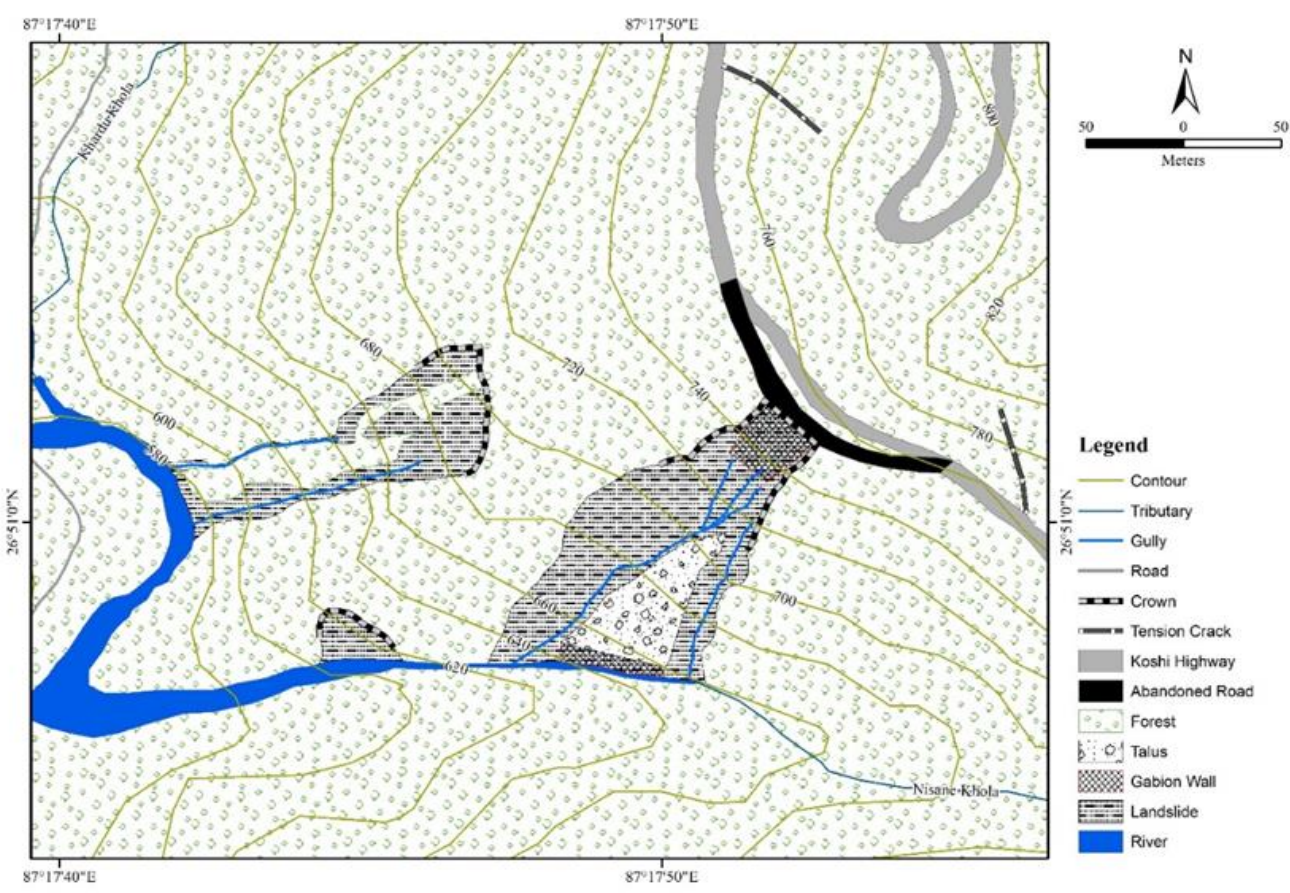

Fig. 5: Map representing landslide and landuse of the site

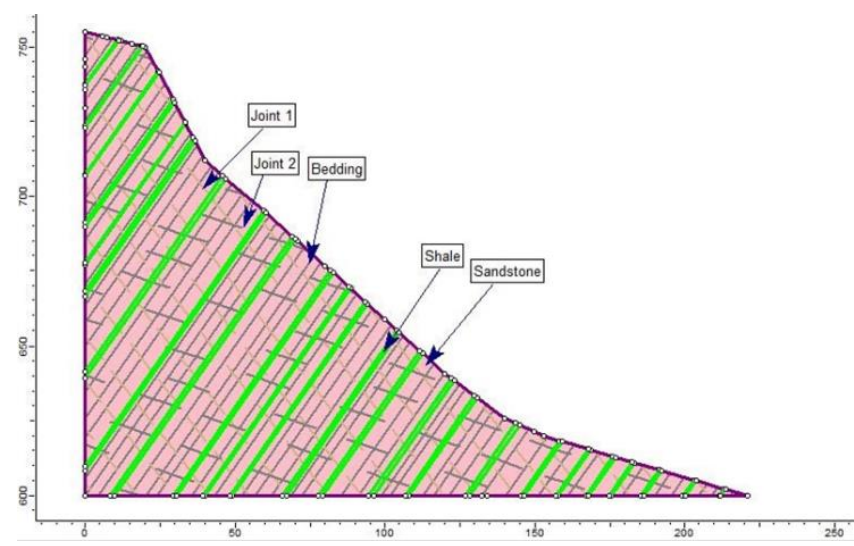

Fig. 6: Map representing cross-section view of the landslide

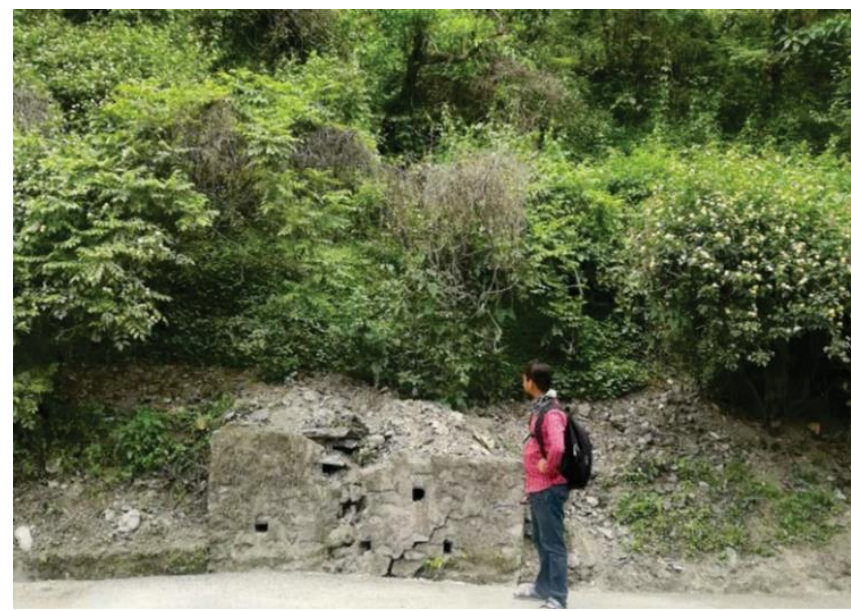

Fig. 7: Development of the tension crack destroys the wall installed for slope stabilization along the Koshi Highway

the Sardu Khola and little gentler slope may be the reason for other scarps not to increase as rapid as the major slide.

The approach has been made in order to find out the events of landslide and its propagation through time.
For this purpose, the satellite images from Google Earth Pro (Fig. 8 and 9) of different time interval was studied and analyzed. The topographical map 2687 02C of Dharan area published by Department of Survey, Government of Nepal in 1995 A.D. represents markings of landslides in the present study area. This concludes landslide to be older one. The Google image of 2004 A.D. represents intense scars on the Koshi Highway side of the Nisane Khola. The slides seem passive till 2009 A.D. with developing vegetation cover. Whereas, in the image of 2014 A.D., no real trace of landslide can be observed as the site has been covered by vegetation. In early 2015 A.D., slight scouring of the slope can be observed. The sliding intensified after the series of earthquake and aftershocks of Gorkha Earthquake 2015 A.D. The image of 2016 A.D. shows the slide has reached up to the Koshi Highway. Some mitigation measures applied on the toe portion by installing gabion wall, which caused the slide to disperse in its periphery and is evident by the imagery of 2018 A.D. showing deep gullies on the western and eastern section of the main landslide.

\subsection{Geotechnical study}

The kinematic analysis, $\mathrm{RMR}_{\text {basic }}$ and SMR were carried out at eight different slope faces of landslides as indicated in Fig. 9. The data related with joints sets and friction angle were analyzed, and the stereographs are as shown in the Fig. 10. The area consists alternating beds of sandstone and shale dipping 


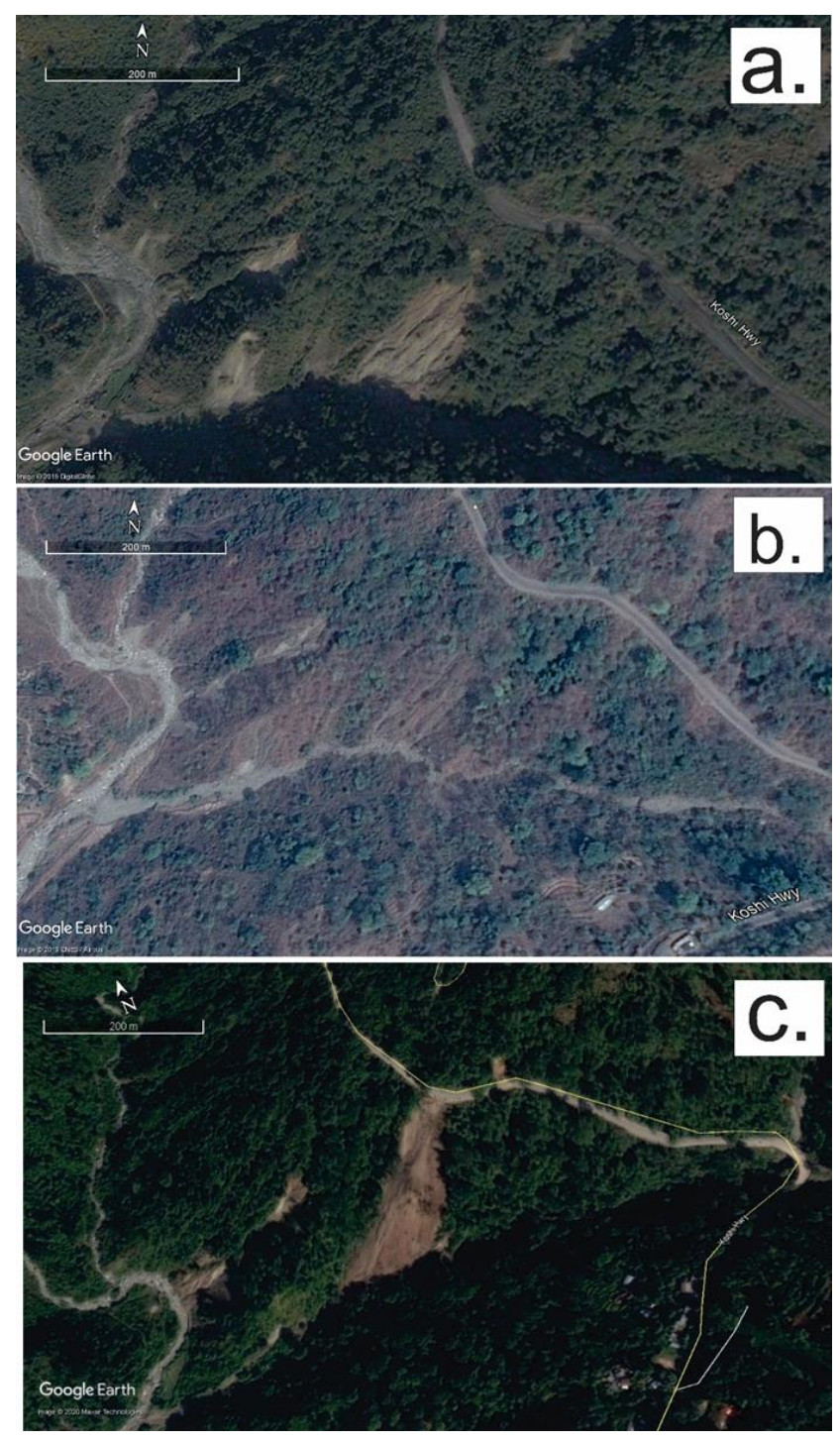

Fig. 8: Temporal images of Nisane Landslide from Google Earth Pro (a) 2004 A.D. (b) 2014 A.D. and (c) 2016 A.D. northeast, whereas major joint sets are southeast and southwest dipping. From the kinematic analysis (Table 1), it can be observed that except for location 1 all the slopes are suffering through wedge failure mostly trending southwest. Locations 2 and 3 have more severe condition as these slopes has risk of plane failure too. In case of slope 1 and 8 , there is chances of toppling failures (Fig. 10). The failure is intense at the slightly southwest facing slopes of the major slide comprising locations 2, 3 and 4 whereas at the westward facing slope, less severity can be observed. This is due to the southwest trend of majority of failure plains and the failure supporting slope aspect of location 2, 3 and 4 .

The results of $\mathrm{RMR}_{\text {basic }}$ analysis has shown that majority of slopes (Slope 1, 3, 4, 5, 6, 8) comprises of discontinuities properties of Fair Class or Class C (41$60)$. In case of slope 2, 7 the values area slightly less and indicates the rocks are in the geotechnical state of Class D (21-40) or Poor Rock Class.

The results of kinematic analysis (Table 1 ), $\mathrm{RMR}_{\text {basic }}$ (Table 2) and the data related to joint surface were used for the calculation of SMR (Table 3). The calculations indicated that, the wedge of slope 2 , the plain and wedge (W2) of slope 3 , and the topple of slope 8 seems vulnerable and unstable. In case, the plain of slope 2 , the wedges (W2 and W3) of slope 3 and the wedges of slopes 4, 5, 6, 7, 8 are partially stable. However, the topple of the slope 1 seems to be stable in present condition.

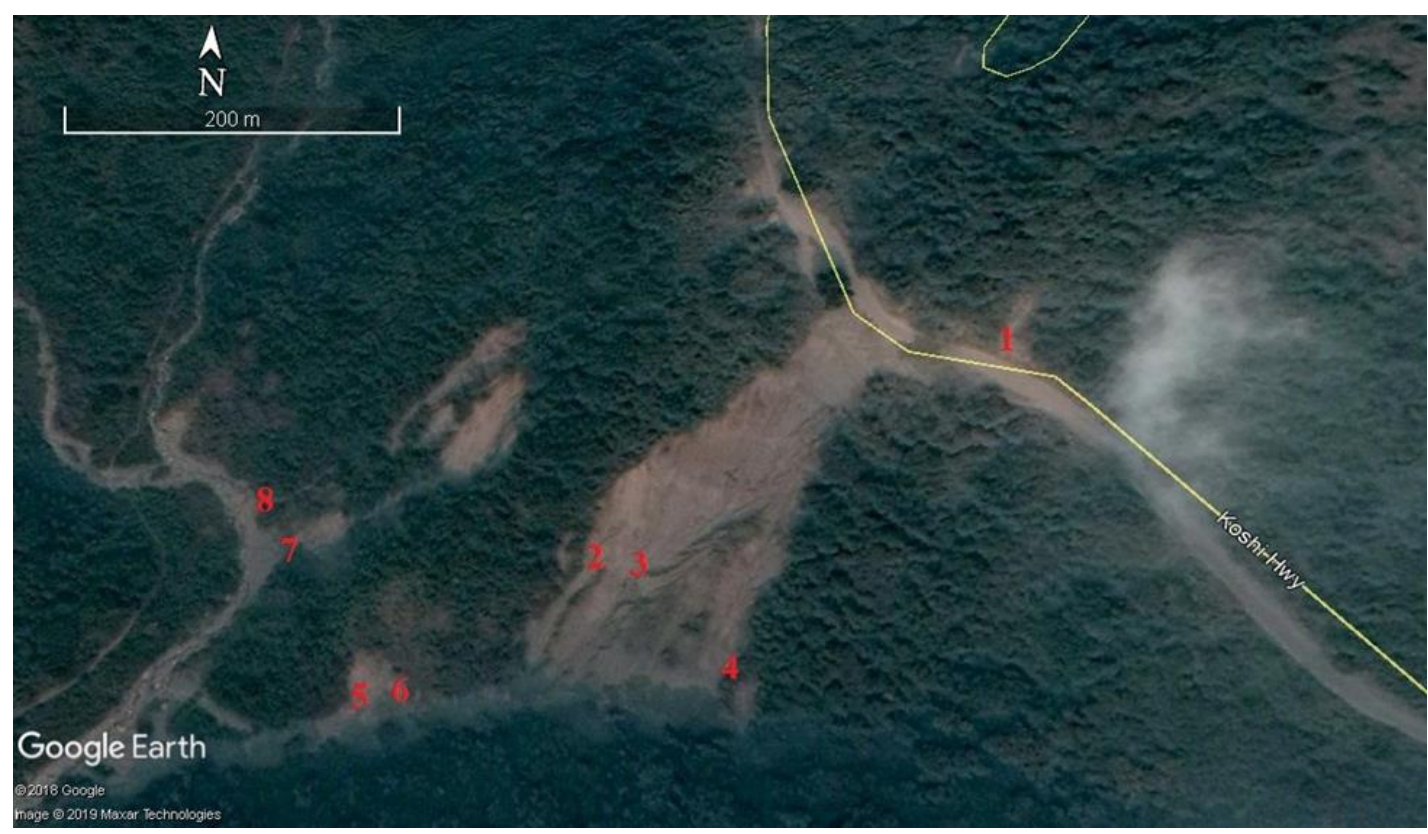

Fig. 9: Aerial image of 2018 A.D. from Google Earth Pro showing the locations (Numbers 1-8) chosen for slope stability analysis 


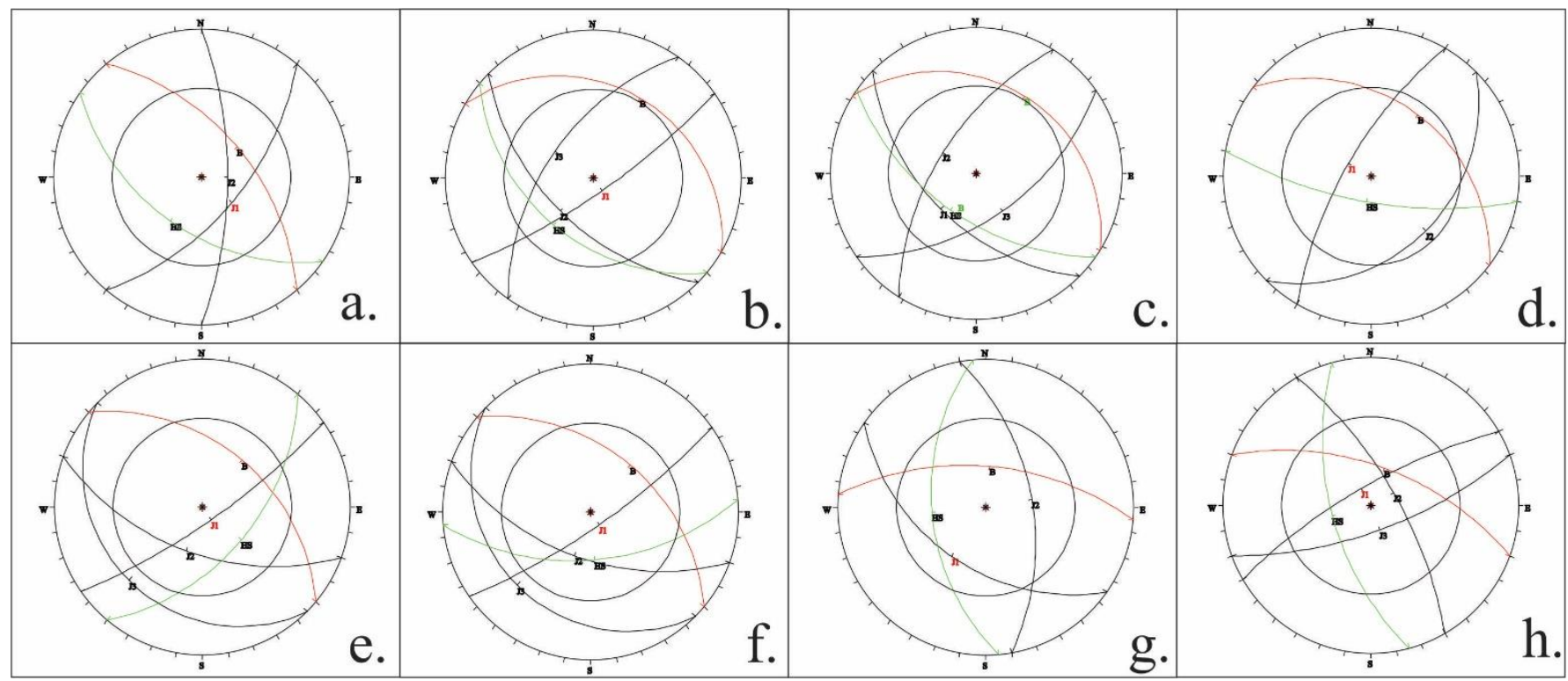

Fig. 10: Kinematic analysis of hillslope a. slope 1, b. slope 2, c. slope 3, d. slope 4, e. slope 5, f. slope 6, g. slope 7, h. slope 8

Table 1: The kinematic analysis of different slopes (Slope 1-8) of the Nisane Landslide

\begin{tabular}{|c|c|c|c|c|c|c|c|c|}
\hline \multirow[t]{2}{*}{ Slope } & \multicolumn{4}{|c|}{ Discontinuities } & \multirow{2}{*}{$\begin{array}{l}\text { Hill } \\
\text { Slope }\end{array}$} & \multicolumn{3}{|c|}{ Failure } \\
\hline & Bedding & $\mathrm{J} 1$ & $\mathrm{~J} 2$ & $\mathrm{~J} 3$ & & Plane & Wedge & Topple \\
\hline 1 & $50^{\circ} / 55^{\circ}$ & $130^{\circ} / 60^{\circ}$ & $90^{\circ} / 70^{\circ}$ & & $215^{\circ} / 50^{\circ}$ & & & $\begin{array}{l}\text { Bedding } \\
\text { Plane }\end{array}$ \\
\hline 2 & $30^{\circ} / 26^{\circ}$, & $145^{\circ} / 78^{\circ}$ & $225^{\circ} / 55^{\circ}$ & $305^{\circ} / 55^{\circ}$ & $220^{\circ} / 45^{\circ}$ & $\mathrm{J} 2$ & $\begin{array}{c}\mathrm{J} 1 \& \mathrm{~J} 3(\mathrm{w} 1)= \\
230^{\circ} / 21^{\circ}\end{array}$ & \\
\hline 3 & $32^{\circ} / 26^{\circ}$ & $225^{\circ} / 52^{\circ}$ & $302^{\circ} / 60^{\circ}$ & $145^{\circ} / 55^{\circ}$ & $215^{\circ} / 56^{\circ}$ & $\mathrm{J} 1$ & $\begin{array}{c}\mathrm{J} 1 \& \mathrm{~J} 3 \\
(\mathrm{w} 2)=188^{\circ} / 46^{\circ},\end{array}$ & \\
\hline & & & & & & & $\begin{array}{c}\mathrm{J} 1 \underset{\mathrm{J}}{2}(\mathrm{w} 3)= \\
252^{\circ} / 59^{\circ}\end{array}$ & \\
\hline & & & & & & & $\begin{array}{c}\mathrm{J} 2 \& \mathrm{~J} 3(\mathrm{w} 1)= \\
221^{\circ} / 18^{\circ}\end{array}$ & \\
\hline 4 & $37^{\circ} / 35^{\circ}$ & $300^{\circ} / 70^{\circ}$ & $135^{\circ} / 35^{\circ}$ & & $190^{\circ} / 70^{\circ}$ & & $\begin{array}{c}\mathrm{J} 1 \& \mathrm{~J} 2(\mathrm{w} 1)= \\
212^{\circ} / 08^{\circ}\end{array}$ & \\
\hline 5 & $40^{\circ} / 45^{\circ}$ & $145^{\circ} / 78^{\circ}$ & $200^{\circ} / 55^{\circ}$ & $225^{\circ} / 20^{\circ}$ & $130^{\circ} / 52^{\circ}$ & & $\begin{array}{l}\text { Bedding and } \mathrm{J} 2(\mathrm{w} 1) \\
\quad=117^{\circ} / 11^{\circ}\end{array}$ & \\
\hline 6 & $40^{\circ} / 45^{\circ}$ & $145^{\circ} / 78^{\circ}$ & $200^{\circ} / 55^{\circ}$ & $225^{\circ} / 20^{\circ}$ & $175^{\circ} / 54^{\circ}$ & & $\begin{array}{c}\mathrm{J} 1 \& \mathrm{~J} 2(\mathrm{w} 1)= \\
224^{\circ} / 43^{\circ}\end{array}$ & \\
\hline 7 & $5^{\circ} / 59^{\circ}$ & $215^{\circ} / 46^{\circ}$ & $80^{\circ} / 55^{\circ}$ & & $265^{\circ} / 50^{\circ}$ & & $\begin{array}{l}\text { Bedding and } \mathrm{J} 1 \text { (w1) } \\
\quad=286^{\circ} / 18^{\circ}\end{array}$ & \\
\hline 8 & $20^{\circ} / 60^{\circ}$ & $330^{\circ} / 75^{\circ}$ & $60^{\circ} / 70^{\circ}$ & $160^{\circ} / 70^{\circ}$ & $255^{\circ} / 60^{\circ}$ & & $\begin{array}{c}\mathrm{J} 1 \& \mathrm{~J} 3(\mathrm{w} 1)= \\
244^{\circ} / 15^{\circ}\end{array}$ & $\mathrm{J} 2$ \\
\hline
\end{tabular}


Table 2: The ratings of $\mathrm{RMR}_{\text {basic }}$ of different slopes (1-8) of the Nisane landslide

\begin{tabular}{cccccccccc}
\hline \multirow{2}{*}{ Slope } & $\begin{array}{c}\text { Strength of } \\
\text { Intact rock }\end{array}$ & RQD & Spacing & \multicolumn{5}{c}{ Condition of Discontinuities } & \multicolumn{2}{c}{$\begin{array}{c}\text { Ground water } \\
\text { Condition }\end{array}$} \\
\cline { 5 - 10 } & & & $\begin{array}{c}\text { Persist } \\
\text { ence }\end{array}$ & Separation & $\begin{array}{c}\text { Rough } \\
\text { ness }\end{array}$ & $\begin{array}{c}\text { Infilli } \\
\text { ngs }\end{array}$ & $\begin{array}{c}\text { Weath } \\
\text { ering }\end{array}$ \\
\hline 1 & 7 & 8 & 8 & 4 & 1 & 3 & 2 & 3 & 15 \\
2 & 4 & 3 & 5 & 4 & 1 & 3 & 2 & 3 & 15 \\
3 & 7 & 8 & 10 & 6 & 1 & 5 & 2 & 3 & 7 \\
4 & 7 & 3 & 8 & 4 & 1 & 3 & 2 & 3 & 15 \\
5 & 4 & 3 & 8 & 4 & 4 & 3 & 2 & 3 & 15 \\
6 & 4 & 3 & 8 & 4 & 4 & 3 & 2 & 3 & 15 \\
7 & 4 & 3 & 5 & 4 & 1 & 5 & 2 & 3 & 10 \\
8 & 4 & 3 & 5 & 4 & 4 & 3 & 2 & 3 & 15 \\
\hline
\end{tabular}

Table 3: Results of slope mass rating for different slopes (1-8) of the Nisane landslide

\begin{tabular}{|c|c|c|c|c|c|}
\hline Slope & RMR & Main lithology & $\begin{array}{l}\text { Slope Mass } \\
\text { Rating }\end{array}$ & Stability & Failures \\
\hline 1 & 51 & Greenish grey sandstone & $\mathrm{T} 1=66$ & Stable & Some Blocks \\
\hline & & Bluish, grey to pinkish sandstone & & Partially stable & $\begin{array}{l}\text { Some joints or } \\
\text { many wedges }\end{array}$ \\
\hline 2 & 40 & $\begin{array}{l}\text { alternating with purple to grey } \\
\text { mudstone }\end{array}$ & $\mathrm{W} 1=38$ & Unstable & $\begin{array}{l}\text { Planar or big } \\
\text { wedges }\end{array}$ \\
\hline \multirow{4}{*}{3} & \multirow{4}{*}{49} & \multirow{4}{*}{$\begin{array}{l}\text { Bluish, grey to pinkish sandstone } \\
\text { alternating with purple to grey } \\
\text { mudstone }\end{array}$} & $\mathrm{P} 1=29$ & Unstable & $\begin{array}{l}\text { Planar or big } \\
\text { wedges }\end{array}$ \\
\hline & & & $\mathrm{W} 1=56$ & Partially stable & $\begin{array}{l}\text { Some joints or } \\
\text { many wedges }\end{array}$ \\
\hline & & & $\mathrm{W} 2=40$ & Unstable & $\begin{array}{c}\text { Planar or big } \\
\text { wedges }\end{array}$ \\
\hline & & & $\mathrm{W} 3=56$ & Partially stable & $\begin{array}{l}\text { Some joints or } \\
\text { many wedges }\end{array}$ \\
\hline 4 & 46 & $\begin{array}{l}\text { Bluish, grey to pinkish sandstone } \\
\text { alternating with purple to grey } \\
\text { mudstone }\end{array}$ & $\mathrm{W} 1=57$ & Partially stable & $\begin{array}{l}\text { Some joints or } \\
\text { many wedges }\end{array}$ \\
\hline 5 & 46 & Sandstone and grey to black shale & $\mathrm{W} 1=55$ & Partially stable & $\begin{array}{l}\text { Some joints or } \\
\text { many wedges }\end{array}$ \\
\hline 6 & 46 & Sandstone and grey to black shale & $\mathrm{W} 1=55$ & Partially stable & $\begin{array}{l}\text { Some joints or } \\
\text { many wedges }\end{array}$ \\
\hline 7 & 37 & $\begin{array}{c}\text { Sandstone and grey, black and purple } \\
\text { shale }\end{array}$ & $\mathrm{W} 1=48$ & Partially stable & $\begin{array}{l}\text { Some joints or } \\
\text { many wedges }\end{array}$ \\
\hline \multirow{2}{*}{8} & \multirow{2}{*}{43} & \multirow{2}{*}{ Sandstone } & $\mathrm{W} 1=52$ & Partially stable & $\begin{array}{l}\text { Some joints or } \\
\text { many wedges }\end{array}$ \\
\hline & & & $\mathrm{T} 1=40$ & Unstable & $\begin{array}{l}\text { Planar or big } \\
\text { wedges }\end{array}$ \\
\hline
\end{tabular}

\section{Conclusions}

The study area has been classified into the Chiuribas Formation of the Lesser Himalaya, the Tamrang Formation of the Gondwana sequence of the Lesser Himalaya and rocks of the lower member and upper member of Lower Siwalik Formation. The Dharapani Thrust and the Main Boundary Thrust are the major thrusts present within the close horizontal distance indicating multiple phase of intense deformation. The
Nisane Landslide itself is an old one but its activeness has varied through time. The recent slide activity has initiated after the Gorkha Earthquake, 2015 (Fig. 8 b and c) and it is continuing. Some damaged structures due to ground displacement and bent stem of trees indicate the ground is moving downslope slowly. The high precipitation rate and the toe scouring of Nisane Khola may further intensify the failure in due time.

From the kinematic analysis, the wedge failure is 
the prominent mode of failure. The toppling possibility exists on location 1 (crown part) and 8, whereas, at location 2 and 3 the wedge failure is accompanied with plane failure. From the RMR basic analysis, majority of rock mass falls within Class $\mathrm{C}$ or the fair class. The SMR analysis shows most of the slopes are only partially stable to unstable and needs support for stabilization. The result of SMR suggested that the slopes of location 2, 3 and 4 of main scarp require special attention and the shotcrete along with rock bolting are recommended for slope stabilization.

\section{Acknowledgments}

The authors are thankful to the Campus Chief, Asst. Campus Chief and the Research Committee for continuous support and suggestions since proposal screening. The authors are equally grateful to students of B.Sc. Geology 4th year, 2072 batch for their help during the field work.

\section{Conflicts of Interest}

The authors state no conflicts of interest. The authors alone are responsible for composing the paper.

\section{Funding}

The intended research has been conducted as the Faculty Research Grant- 2019 of Central Campus of Technology, Dharan.

\section{References}

Adhikari, D., Shrestha, K., Adhikari, P., Paudayal, K. N., \& Paudel, L. (2018). Geological study of Chatara-Barahakshetra section, Sunsari-Udayapur District, eastern Nepal. Bulletin of the Department of Geology, 49-58.
Bieniawski, Z. T. (1989). Engineering rock mass classifications: a complete manual for engineers and geologists in mining, civil, and petroleum engineering. John Wiley \& Sons.

Dhital, M. R. (2015). Geology of the Nepal Himalaya: regional perspective of the classic collided orogen. Springer.

DMG. (2009). Engineering and environmental geological map of Dharan Area.

DMG. (2011). Geological map of eastern Nepal.

Hoek, E., \& Bray, J. W. (1981). Rock slope engineering, institute of mining and metallurgy. London, England, 358.

Hoek, E., \& Brown, E. T. (1997). Practical estimates of rock mass strength. International journal of rock mechanics and mining sciences, 34(8), 1165-1186.

Rai, L. K., Acharya, K. K., \& Dhital, M. R. (2016). Lithostratigraphy and structure of the DharanMulghat area, Lesser Himalayan sequence, eastern Nepal Himalaya. Journal of Nepal Geological Society, 51, 77-78.

Riquelme, A., Tomas, R., \& Abellan, A. (June 18 2019). SMRTool beta. A calculator for determining Slope Mass Rating (SMR). Universidad de Alicante.

http://personal.ua.es/es/ariquelme/smrtool.html

Romana, M. (1985). New adjustment ratings for application of Bieniawski classification to slopes. In Proceedings of the international symposium on role of rock mechanics, Zacatecas, Mexico (pp. 49-53). 